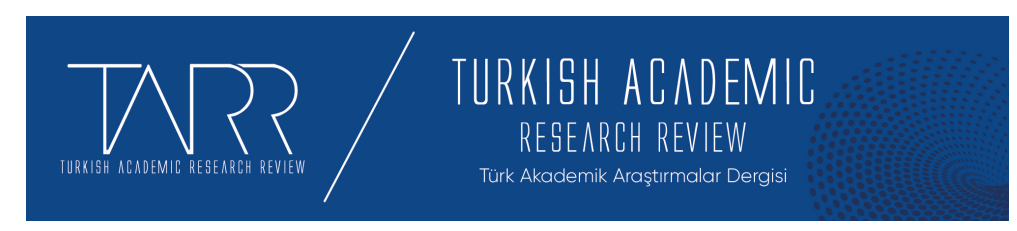

e-ISSN: 2602-2923

Yıl/Year: 2021 Cilt/Volume: 6 Sayı/Issue: 1

\title{
Ebû Alî el-Fârisî’nin Hayatı ve et-Tekmile İsimli Eserinde Metodolojisi
}

The Life of Abu Ali Al-Farisi And His Methodology In His Work Titled Al-Takmilah

\section{Recep KIRCI}

Öğr. Gör. Dr., Pamukkale Üniversitesi İlahiyat Fakültesi, Arap Dili ve Belagatı ABD, rkirci@pau.edu.tr, Orcid ID: 0000-0003-0893-6885

\begin{tabular}{r|l} 
Makale Bilgisi & Article Information \\
Makale Türü - Article Type & Araştırma Makalesi / Research Article \\
Geliş Tarihi - Date Received & 14 Şubat / February 2021 \\
Kabul Tarihi - Date Accepted & 22 Mart / March 2021 \\
Yayın Tarihi - Date Published & 25 Mart / March 2021 \\
Yayın Sezonu & Ocak - Şubat - Mart \\
Pub Date Season & January - February - March
\end{tabular}

Atıf / Cite as: Kırcı, Recep, Ebû Alî el-Fârisî’nin Hayatı ve et-Tekmile İsimli Eserinde Metodolojisi/The Life of Abu Ali Al-Farisi And His Methodology In His Work Titled Al-Takmilah. tarr: Turkish Academic Research Review, 6 (1), 335-354. doi: 10.30622 tarr. 880208

Intihal / Plagiarism: Bu makale, en az iki hakem tarafından incelenmiş ve intihal içermediği teyit edilmiştir. / This article has been reviewed by at least two referees and confirmed to include no plagiarism. https://dergipark.org.tr/tr/pub/tarr

Copyright (C) Published by Mehmet ŞAHIN Since 2016- Akdeniz University, Faculty of Theology, Antalya, 07058 Turkey. All rights reserved.

Turkish Academic Research Review - Türk Akademik Araştırmalar Dergisi https://dergipark.org.tr/tr/pub/tarr 


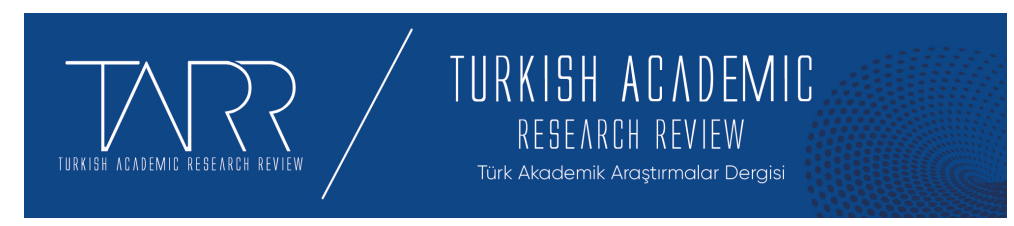

e-ISSN: 2602-2923

Yıl/Year: 2021

Cilt/Volume: 6

Sayı/Issue: 1

\title{
Ebû Alî el-Fârisî’nin Hayatı ve et-Tekmile İsimli Eserinde Metodolojisi ${ }^{1}$ \\ Recep KIRCI
}

Özet

Hicri IV. yy. İslâm bilim tarihi açısından altın çağ kabul edilmektedir. Bu dönem Arap grameri açısından da Basra ve Küfe ekolünün zayıflayıp; Bağdat'ta iki ekolden birinin görüşlerinin tercih edildiği bir zaman dilimi olarak öne çıkmaktadır. $\mathrm{Bu}$ dönemde yetişen dilcilerden biri olan Ebû Alî el-Fârisî de (ö. 377/987) döneme egemen olan bu duruma uyum göstermiş ve farklı görüşlerin içerisinden kendisine göre doğru olanı tercih etmiştir. Müellif sarf, nahiv lügat ve şiir alanında bir çok çalışma yapıp, otuzdan fazla eser kaleme alan önemli bir âlimdir. el-Fârisî’nin ilmî kişiliğini gösteren ve gelenekte önemli yeri olan eserlerinden biri et-Tekmile'dir. Sözü geçen eser ilk dönem sarf eserlerinden kabul edilmektedir. Çalışmamızda müellifin bu eserde takip ettiği yöntem, müellifin hayatı, eğitimi, hocaları, öğrencileri, seyahatleri ve eserleri ele alınmıștır. Çalıșma esnasında el-Fârisî̀nin yaşadığı dönemden günümüze kadar, hayatı ile ilgili kaleme alınan biyografi eserleri incelenmiş, müellifin et-Tekmile isimli eserinin el yazması ve tahkikli nüshalarına ulaşılmış ve et-Tekmile'nin şerhi olan Cürcânî'nin (ö. 471/1078-79) Kitâbü'lMukteșid isimli eserinden konular takip edilmiştir. Çalışma sonucunda el-Fârisî’nin et-Tekmile isimli eserini kelimedeki değişimi baz alarak hazırladığı ve sözü geçen eserde özgün bir metot takip ettiği tespit edilmiştir.

Anahtar Kelimeler: Arap Dili, Sarf, Ebû Alî el-Fârisî, et-Tekmile, Metot.

\section{The Life of Abu Ali Al-Farisi And His Methodology In His Work Titled Al- Takmilah}

\begin{abstract}
Fourth century a.h. is accepted as golden age in terms of Islamic science history. With regard to Arabic grammar as well, this era stands out as a period in which Basra and Kufa schools were weakened and the views of one of the two schools were preferred in Baghdad. Abu Ali al-Farisi (d. 377/987), one of the linguists who grew up in this period, also adapted to this situation that dominated the period and used to choose the view which was right in his perspective among different views. The author is an important scholar who made many studies in the field of sarf, nahwu, vocabulary, and poetry; and wrote more than thirty works. One of the works that shows the scientific aspect of al-Farisi and which has an important place in the tradition is al-Takmilah. This work is accepted as one of the first period sarf studies. In this article, the method followed by the author in this work, his life, education, teachers, students, travels, and his works are discussed. During this study, biographical works written about the life of al-Farisi from the time he lived up to the present were examined, the manuscript and the authentic copies of al-Takmilah were obtained, and topics from the work of Curcani (d. 471/1078-79) named Kitabu'lMuktashid, which is the commentary of al-Takmilah were followed. As a result of the study, it was concluded that al-Farisi benefited from the views of the linguists
\end{abstract}

\footnotetext{
1 "Ebû Alî el-Fârisî'nin Hayatı ve et-Tekmile İsimli Eserindeki Metodolojisi" adlı bu makale "Ebû Alî el-Fârisî'nin et-Tekmile Adlı Eserindeki Metodolojisi ve Sarf İlmine Dair Görüşleri" isimli Doktora tezinden üretilmiştir.
}

Turkish Academic Research Review - Türk Akademik Araştırmalar Dergisi 
before him, but based on the change in the word in al-Takmilah, it was also concluded that in terms of methodology, he followed his own method in his work.

Keywords: Arabic Language, Sarf, Abu Ali al-Farisi, al-Takmilah, Method. Structured Abstract

Arabic is the first language that comes to mind in the Islamic cultural geography and civilization. The reason for this is that the holy Quran, which is the first source and basic book of Islam, and the prophetic traditions (Hadith) accepted as the second source by most of Islamic scholars are expressed in Arabic language. Muslims of different races, who aim to understand the Quran and the prophetic traditions (hadith) in order to live their religion correctly, as well as nations whose mother tongue is Arabic have made great efforts in preserving this language, determining its rules and transferring it to the next generations. As a result, Arabic has been an important language that many people speak or are interested in since ancient times. Nowadays, considering the existence of Muslims and Arabs who migrated to many parts of the world, it is revealed how wide this language has spread over a geography and is used by millions of people as a mother tongue or a second language. As a matter of fact, recent research proves this fact. Like every language, Arabic, which is such a deep-rooted and common language, has some rules of its own. These rules are syntax, morphology, rhetoric and others are expressed in branches of science. From the first period, Muslim scholars and Arab linguists have made efforts to determine the rules of these sciences and transfer them to the future periods. Hijri IV. Ebû Ali al-Faraisi, who lived in the 4th century AH, was one of the prominent Arabic linguists who devoted his life to the determination of the rules of this language and spent his life for this cause and wrote important works. These works he wrote and his views on morphology, syntax and lexicon influenced many linguists in the following centuries and took their place as a reference in their works.

During the 4th century AH, Basra and Kufa schools weakened in terms of Arabic grammar; It stands out as a period in which the views of one of the two schools are preferred in Baghdad. It is observed that al-Faraisi, who grew up in this period, also benefited from the Kufah and Baghdad schools, although the views of the Basra school were dominant in his works.

Having unique ideas in the field of language, teaching a student like Ibn Cinnî (d. 392/1002) who would be influential in the period after him, and reading his work named al-Îżâh as a source book in madrasas for 300 years put him in the position to be the subject of individual studies has brought. In this context, the method he followed in his work named et-Tekmile, which shows his work on consumption and has an important place in the tradition, has been deemed important for us.

al-Fârisî left more than thirty works on syntax, morphology, qiraat and lexicon that have survived and have not survived. Some of his works were attributed to statesmen such as Seyfüddevle, the Emir of the Hamdânis, and Adududdevle, the Emir of Buyids. In addition, some of his works have been verified and some await investigation. The author, along with taking lessons from the leading scholars of the period he was a part of, also read the writings and syntaxial works written in the period before him.

Islamic cities were centers of science and civilization during the period of al-Faraisi. For this reason, like many of his contemporary scholars, he traveled to different Islamic cities, studied science and taught in each of them. While the rules of 
morphology and syntax were intertwined in most of the works that were written until the time of the author's life, he devoted al-Îżâh for and et-Tekmile for morphology. Al-Fârisî wrote et-Tekmile from the beginning to the end to cover the whole the changes in the word.

While creating his work, the author made use of previous linguists. In this area, Halil b. Ahmed, Sîbeveyhi, Asmaî, Abu Zeyd, Müberred and similar scholars' views. However, among these, the names of Sîbeveyhi and Abu Zayd are more frequently mentioned. He also mentioned the views of scholars such as Kisâi, Ferrâ, Sa'leb from Kufa school, and he did not oppose Sa'leb's views among them. When considered on the basis of language schools, the views of the Basra people are the most striking, but also the views of the Kufa. Although the people of Baghdad are mentioned in some places, the author often opposes them.

He based the rules in al-Fârisî et-Tekmile with methods such as hearing (sema'), analogy (qiyas) and reasoning (ta'lîl). However, among them, Hearing has been the primary source.

al-Faraisi gave priority to the verses of the Quran while founding Arabic grammars depending on sema in et-Tekmile, and then Arabic poetry continued in consultation with the Arabic word, but it was not found any citations with hadiths in this book. He gave special importance to the Arab tribes of the Hijaz and Bani Tamim and accepted their lexicon as the basis. It can be said that basing on the rules of qiyas is the most skillful subject of al-Faraisi.

In et-Tekmile, different divisions have been made sometimes at the beginning of the subject and sometimes in the middle of the subject while explaining the morphology-related topics. In addition to these, definitions are also included.

\section{Giriş}

İslam kültür coğrafyası ve medeniyetinde akla ilk gelen dil Arapçadır. Bunun nedeni İslam'ın ilk kaynağı ve temel kitabı olan Kur'an'ın ve çoğu İslâm âlimi tarafindan ikinci kaynak kabul edilen hadislerin Arap dili ile ifade edilmesidir. Dinlerini sahîh bir şekilde yaşamak için Kur'an'ı ve hadisleri doğru bir şekilde anlamayı amaç edinen farklı ırklara mensup Müslümanların yanı sıra ana dilleri Arapça olan milletler de bu dilin korunmasında, kurallarının belirlenmesinde ve sonraki nesillere aktarılmasında üstün gayretler sarf etmişlerdir. Bunun sonucunda Arapça eski çağlardan beri birçok insanın konuştuğu veya ilgi duyduğu önemli bir dil olmuştur. Günümüzde ise dünyanın birçok yerine göç eden Müslüman ve Arapların varlığı göz önüne alındığında bu dilin ne denli geniş bir coğrafyaya yayıldığı ve milyonlarca insan tarafından anadil veya ikinci dil olarak kullanıldığ ortaya çıkmaktadır. Nitekim son zamanlarda yapılan araştırmalar da bu gerçeği kanıtlamaktadır. Her dil gibi böylesine köklü ve yaygın bir dil olan Arapçanın da kendine ait bazı kuralları vardır. Bu kurallar; nahiv, sarf ve belâgat gibi ilim dalları 
ile ifade edilmektedir. İlk dönemden itibaren Müslüman âlimler ve Arap dil bilimcileri bu bilimlere ait kaidelerin belirlenmesi ve sonraki dönemlere aktarımı için gayret sarf etmişlerdir. Hicri IV. yy.'da yaşayan Ebû Ali el-Fârisî de hayatını bu dilin kurallarının tespitine adayan ve ömrünü bu uğurda geçiren önemli Arap dil bilimcilerinden olup kayda değer önemli eserler kaleme almıştır. Kaleme aldığı bu eserler ve onun sarf, nahiv ve lügate dair görüşleri sonraki asırlarda birçok dilciyi etkilemiş ve eserlerinde başvurulan bir kaynak olarak yerini almıştır.

Hicri IV. yy., Arap grameri açısından Basra ve Kûfe ekolünün zayıfladığı; Bağdat'ta iki ekolden birinin görüşlerinin tercih edildiği bir dönem olarak öne çıkmaktadır. Bu dönemde yetişen el-Fârisî’nin de eserlerinde Basra ekolünün görüşleri baskın olsa da Kûfe ve Bağdat ekolünden de yararlandığı gözlemlenmektedir.

el-Fârisî otuzdan fazla eser kaleme almıştır. Ancak bunların içerisinden elÎzâh fi'n-nahv, et-Tekmile ve el-Hücce li'l-kurrâ'i's-seb'a isimli eserleri kendi döneminde ve sonraki dönemlerde daha etkili olmuştur. Ayrıca el-Fâriŝ̂’nin dil alanında özgün fikirlere sahip olması, kendisinden sonraki dönemde etkili olacak İbn Cinnî (ö. 392/1002) gibi bir öğrenciyi yetiştirmesi ve el-Îzâh isimli eserinin 300 yıl medreselerde kaynak kitap olarak okutulması onu bizatihi müstakil çalışmaların konusu olacak pozisyona getirmiştir. Bu bağlamda onun sarf ile ilgili yaptı̆̆ çalışmaları gösteren ve gelenekte önemli bir yeri olan et-Tekmile isimli eserinde takip ettiği metot bizim açımızdan önemli görülmüştür. Bu çalışmada şu sorulara cevap aranacaktır: el-Fârisî’nin hocaları ve öğrencileri kimlerdir? el-Fârisî etTekmile isimli eserini yazarken kendisinden önceki âlimlerden etkilenmiş midir? Müellif eserini yazarken belli bir sistem takip etmiş midir? Eserde kurallar temellendirirken nasıl bir yöntem takip edilmiştir? $\mathrm{Bu}$ çalışma ile amacımız yukarıdaki sorulara cevap vererek el-Fârisî’nin Arap dili grameri konusunda yaptı̆̆ çalışmaları ve et-Tekmile isimli eserinde takip ettiği metodu ortaya koyarak, ileriki zamanlarda alanla ilgili çalışma yapacakların ve konuya ilgi duyanların istifadesine sunmaktır.

Çalışmamız bir giriş, iki ana bölüm ve bir sonuçtan meydana gelmektedir. Giriş bölümünde konunun önemi, ele alınma nedeni ve takip edilen yöntemi ile kaynakları anlatılmıştır. Birinci bölümde el-Fârisı̂’nin hayatı, seyahatleri, hocaları, öğrencileri ve eserleri yer almaktadır. Bu konular araştırılırken ilk dönemden günümüze kadar el-Fârisî’nin yaşamını ele alan biyografi eserleri, müellif ile ilgili inceleme yapan eserler ve eserlerini tahkik edenlerin yazdığı mukaddimeler incelenmiştir. Bu konuda en çok yararlandığımız klasik ve modern dönem eserleri arasında İbnün-Nedîm'in (ö. 385/995) el-Fihrist'i, İbn Hallikân'ın (ö. 681/1282) 
Vefeyâtü'l-a 'yân'1, Süyûtî'nin (ö. 911/1505) Bugyetü'l-vu 'ât'1, Yâkût el-Hamevî'nin (ö. 626/1229) Mu 'cemü'l-üdebâ's1, İbnü'l-Kıftî'nin (ö. 646/1248) İnbâhü'r-ruvât' '1, Muhsin el-Emîn'in (ö. 1952) A ‘yânü'ş-Şî‘ a'sı, Brockelmann'ın (ö. 1956) Târîhu'ledebi'l-'Arabî'si ve Şelebî'nin el-Fârisi Hayâtühû ve Mekânetühû isimli eserleri yer almaktadır. İkinci bölümde ise el-Fârisi'nin et-Tekmile isimli eseri ile ilgi mâlûmat ve bu eserde takip ettiği metot ve eserin kaynakları yer almaktadır. et-Tekmile incelenirken Kazım Bahr el-Mürcân'ın tahkikini yaptığı eser, Cürcânî’nin etTekmile'yi şerh etmek için yazdığı el-Mukteșid ve Beyazıt kütüphanesine bağlı Veliyyüddîn kütüphanesinde 2903 numarada kayıtlı el yazması nüsha incelenmiştir. İnceleme işlemi esnasında tahkîkli eserlerin bazı yerlerinde hareke ve harf hataları tespit edilmiştir. Sonuç bölümünde ise inceleme neticesinde elde edilen çıarımlar ortaya konulmuştur.

\section{Ebû Alî el-Fârisî’nin Hayatı, Hocaları, Öğrencileri}

\section{1. el-Fârisî'nin Hayatı}

Ebû Alî el-Fârisî'nin asıl adı el-Hasen b. Ahmed b. Abdilgaffâr'dır. ${ }^{2}$ Bazıları buna dedelerinden Muhammed, ${ }^{3}$ Süleyman ${ }^{4}$ ve Ebân' ${ }^{5}$ isminin akabinde de

2 İbnu'n-Nedîm, Ebü’l-Ferec Muhammed b. Ebî Ya‘kūb İshâk b. Muhammed b. İshâk enNedîm, el-Fihrist, Dâru'l Ma'rife, Beyrut, s. 95; Bağdâdî, Ebû Bekr Ahmed b. Alî b. Sâbit, Târîhu Medîneti's-selâm, thk. Beşşâr Avvâd Ma'rûf, Dâru'l-Garbi'l-İslâmî, Beyrut 1422/2001, c. VIII, s. 217; İbnu'l-Enbârî, Ebü'l-Berekât Kemâlüddîn Abdurrahmân b. Muhammed b. Ubeydillâh, Nüzhetü'l-elibbâ' fì tabakâti'l-üdebâ', thk. İbrahim es-Sâmirâî Mektebetü'l-Menâr, Ürdün 1405/1985, s. 232; Yâkūt el-Hamevî, Ebû Abdillâh Şihâbüddîn Yâkūt b. Abdillâh el-Hamevî el-Bağdâdî er-Rûmî, Mu'cemü'l-üdebâ' (İrşâü'l-erîb ilâ ma 'rifeti'l-edîb), thk. İhsân Abbâs, Dâru'l-Garbi'l-İslâmî, Beyrut 1993, c. II, s. 811; İbnü'lKıftî, Ebü'l-Hasen Cemâlüddîn Alî b. Yûsuf b. İbrâhîm b. Abdilvâhid eş-Şeybânî el-Kıftî, Inbâhü'r-ruvât 'alâ enbâhi'n-nühât, thk. Muhammed Ebü'l-Fadl İbrahim, Dâru'l-Fikri'lArabî, Kahire 1406/1986, c. I, s. 308; İbn Hallikân, Ebü’l-Abbâs Şemsüddîn Ahmed b. Muhammed b. İbrâhîm b. Ebî Bekr b. Hallikân el-Bermekî el-İrbilî, Vefeyâtü'l-a yân ve enbâ'ü ebnâ 'i'z-zamân, thk. İhsan Abbas, Dâru Sâdır, Beyrut, c. II, s. 80; Cezerî, Ebü'l-Hayr Şemsüddin Muhammed b. Muhammed b. Muhammed b. Alî b. Yûsuf el-Cezerî, Ġāyetü'n Nihâye fì tabakāti'l-kurrâ', thk. G. Bergstraesser, Dârü'l-Kütübi'l-İlmiyye , Beyrut 1971, c. I, s. 189; Ebü'l-Fazl Şihâbüddîn Ahmed b. Alî b. Muhammed el-Askalânî, Lisânü'l-mîzân, thk. Abdulfettah Ebû Gudde, Dâru'l-Beşâiri'l- İslâmiyye, Beyrut 1423/2002, c. III, s. 26; Süyûtî, Ebü’l-Fazl Celâlüddîn Abdurrahmân b. Ebî Bekr b. Muhammed el-Hudayrî es- Süyûtî eş-Şâfi, Buġyetü'l-vu'ât fì tabakāti'l-lugaviyyîn ve'n-nühât, thk. Muhammed Ebü'l-Fadl İbrâhim, Matbaatu İsâ el-Bâbî el-Halebî ve Şurekâuhû, yy. 1384/1964, c. I, s. 496; Âmilî, Ebû Muhammed el-Bâkır Muhsin b. Abdilkerîm b. Alî el-Hüseynî el-Âmilî, $A$ ‘yânü’ş-Şî‘ $a$, thk.

Turkish Academic Research Review - Türk Akademik Araştırmalar Dergisi 
doğduğu yerlere nispetle el-Fârisî, ${ }^{6}$ el-Fesevî, ${ }^{7}$ ve eş-Şirâzîi ${ }^{8}$ nisbelerini, sahip olduğu ilimdeki derecesinden dolayı da el-İmam, ${ }^{9}$ en-Nahvî el-Meşhûr ${ }^{10}$ ve el-Edîb ${ }^{11}$ sıfatlarını ilave etmişlerdir. Künyesi kaynaklarda da ifade edildiği üzere tartışmasız Ebû Alî'dir. ${ }^{12}$ Müellifin doğum yeri Fâris'in beldelerinden biri olan Fese'dir. ${ }^{13}$ el-

Hasan el-Emîn, Dâru't-teâruf li'l-Matbûa‘, Beyrut 1304/1983, c. V, s. 7; Carl Brockelmann, Târîhu'l-edebi'l-'Arabî, trc. Abdülhalîm en-Neccâr, Dâru'l-Meârif, Kahire tsz., c. II, s. 190; Ömer Ferrûh, Târîhu'l-edebi'l- 'Arabî el-A'suru'l-Abbâsiyye, Dâru'l-İlm li'l-Melâyîn, Beyrut 1401/1981, c. II, s. 536; Şevkī Dayf, el-Medârisü'n-nahviyye, Dâru'l-Meârif, Kahire tsz., 255; Mahmûd Hüseynî Mahmûd, el-Medresetü'l-Baġdâdiyye fì Târîhi'n-Nahvi'l-Arabî, Dâru Ammâr, Amman tsz., s. 260; Muhammed el-Muhtâr Vülid Ebbâh, Târîhu'n-naḥvi'l-Arabî fi'l-Meşrik ve'l-Megrib, Dârü'l-Kütübi'l-i̇lmiyye, Beyrut 1429/2008, s. 185.

3 İbn Hallikân, Vefeyâtü'l-a yân, c. II, s. 80; Süyûtî, Bugyyetü'l-vu'ât , c. I, s. 496; el-Emîn, A ‘yânü'ş-Şî‘'a, c. V, s. 7; Brockelmann, Târîhu'l-edebi'l-'Arabî, c. 2, s. 190; Mahmûd Hüseynî Mahmûd, el-Medresetü'l-Baġdâdiyye fî Târîhi'n-Nahvi 'l-Arabî, s. 260.

${ }^{4}$ Yâkūt el-Hamevî, Mu 'cemü'l-üdebâ', c. II, s. 811; İbnü'l-Kıftî, İnbâhü'r-ruvât, c. I, s. 308; İbn Hallikân, Vefeyâtü'l-a yân, c. II, s. 80; İbnü'l-Cezerî, Ġāyetü’n-Nihâye, c. I, s. 189; Süyûtî , Buggyetü'l-vu'ât, c. I, s. 496; Brockelmann, Târîhu'l-edebi'l-'Arabî, c. II, s. 190; Mahmûd Huseynî Mahmûd, el-Medresetü'l-Bagdâdiyye, s. 260.

5 İbnü'l-Kıftî, İnbâhü'r-ruvât, c. I, s. 308; İbnü'l-Cezerî, Ġāyetü'n-Nihâye, c. I, s. 189; Dayf, el-Medârisü'n-nahviyye, s. 255; Mahmûd Huseynî Mahmûd, el-Medresetü'l-Baġdâdiyye, s. 260.

${ }^{6}$ İbnü'l-Enbârî, Nüzhetü'l-elibbâ', s. 232; Yâkūt el-Hamevî, Mu 'cemü'l-üdebâ', c.

II, s. 811; İbnü'l-Kıftî, İnbâhü'r-ruvât, c. I, s. 308; İbn Hallikân, Vefeyâtü'l- a yân, c. II, s. 80; Askalânî, Lisânü'l-mîzân, c. III, s. 26; Mahmûd Huseynî Mahmûd, el-Medresetü'lBag̀dâdiyye fî Târîhi'n-Nahvi'l-Arabî, s. 260.

7 Ebû Bekr Muhammed b. el-Hasen ez-Zübeydî el-Endülûsî, Tabakātü'n-nahviyyîn ve'lluġaviyyîn, thk. Muhammed Ebû'l-Fadl İbrahim, Dâru'l-Meârif, Kahire tsz., s. 120; el-Emîn, A'yânü’ş-Şî‘'a, c. V, s. 7; Brockelmann, Târîhu’l-edebi’l-’Arabî, c. II, s. 190; Ferrûh, Târîhu'l-edebi'l-'Arabî, c. II, s. 536.

${ }^{8}$ Brockelmann, Târîhu'l-edebi'l-'Arabî, c. II, s. 190; Ferrûh, Târîhu'l-edebi'l-'Arabî, c. II, s. 536.

9 İbnü'l-Cezerî, Ġāyetü'n-Nihâye, c. I, s. 189; Süyûtî , Buggyetü'l-vu'ât, c. I, s. 496.

10 İbnü'n-Nedîm, el-Fifrist, s. 95; İbn'ül-Enbârî, Nüzhetü'l-elibbâ', s. 232; İbnü'l-Kıftî, İnbâhü'r-ruvât, c. I, s. 308; İbnü'l-Cezerî, Ġāyetü'n-Nihâye, c. I, s. 189; Askalânî, Lisânü'lmîzân, c. III, s. 26; el-Emîn, $A$ 'yânü'ş-Şì' $a$, c. V, s. 7.

11 el-Emîn, $A$ 'yânü’ş-Şî‘ $a$, c. V, s. 7.

12 İbnü’n-Nedîm, el-Fifrist, s. 95; el-Emîn, $A$ ‘yânü'ş-Şî‘ a, c. V, s. 7.

13 İbnü'l-Kıftî, İnbâhü'r-ruvât, c. I, s. 308; İbnü'l-Cezerî , Ġāyetü'n-Nihâye, c. I, s. 189; elEmîn, A'yânü'ş-Şî‘'a, c. V, s. 7; Brockelmann, Târîhu'l-edebi’l-’Arabî, c. II, s. 190; Ferrûh, 
Fârisî’nnin annesi aslen Arap olup daha sonra Fâris'e göç eden, Şeyban oğullarına bağlı Rebîatü'l-Feres kolundan gelen Südüs kabilesindendir. ${ }^{14}$ Müellifin babasının adı Ahmed, dedesinin adı Abdulgaffầ'dır. ${ }^{15}$ Bağdâdî (ö. 463/1071); Muhammed b. Ebî el-Fevâris'den müellifin 377/987'de vefat ettiğini nakletmiştir. ${ }^{16}$ el-Fârisî’nin Bağdat'ta eş-Şunniziyye kabristanlığında Ebû Bekr er-Râzî el-Fıkhî’nin (ö. 370/ 981) kabrinin yanına defnedildiği kaynaklarda geçmektedir. ${ }^{17}$

\subsection{Seyahatleri}

Birçok bilim insanının, ilim tahsili veya devlet adamlarının kendilerine yaptıkları davete icabet etmek ve onların himayelerine girmek için seyahatler yaptı̆̆ bilinir. İşte el-Fârisî de bu âlimlerden biridir. ${ }^{18}$ Konuya ilişkin araştırma yapanların bir kısmı el-Fâriŝ̂’’nin seyahatlerini farklı nedenlere bağlamışlar ve onun bu tutkusuna işaret etmişlerdir. ${ }^{19}$ Halife Muktedir (ö. 320/932) döneminde 307/919 yılında ilim öğrenmek için Bağdat'a giden el-Fârisî’nin bu yıllarda 19'lu yaşlarda olduğu tahmin edilmektedir. ${ }^{20} 341$ senesinde Bağdat'ta eğitimini tamamladıktan sonra ${ }^{21}$ Şam beldeleri, ${ }^{22}$ Trablus ${ }^{23}$ ve Halep'e uğramış, ayrıca orada Seyfüddevle'nin (ö. 356/967) sarayında belli bir süre kalmıştır. Yazar, daha sonra Adududdevle tarafından yapılan davetten dolayı Fâris'e (Şiraz’a) gidecektir. Zira Adududdevle,

Târîhu'l-edebi'l-'Arabî, c. II, s. 536; Dayf, el-Medârisü'n-nahviyye, s. 255; Mahmûd Huseynî Mahmûd, el-Medresetü'l-Bagdâdiyye, s. 260.

${ }^{14}$ Yâkūt el-Hamevî, Mu'cemü'l-üdebâ', c. II, s. 811; Askalânî, Lisânü'l-mîzân, c. III, s. 26; Brockelmann, Târîhu'l-edebi'l-'Arabî, c. II, s. 190; Dayf, el-Medârisü'n-nahviyye, s. 255; Ferrûh, Târîhu'l-edebi'l-'Arabî, c. II, s. 536.

15 İbnü'n-Nedîm, el-Fifrist, 95; İbnü'l-Enbârî, Nüzhetü'l-elibbâ', s. 232; İbnü'l-Kıftî, İnbâhü'r-ruvât, c. I, s. 308; İbnü'l-Cezerî, Ġāyetü'n-Nihâye, c. I, s. 189; İbn Hallikân, Vefeyâtü'l-a 'yân, c. II, s. 80; Süyûtî, Buggyetü'l-vu'ât, c. I, s. 496.

16 Bağdâdî, Târîhu Medîneti's-selâm, c. VIII, s. 217.

17 İbn Hallikân, Vefeyâtü’l-a 'yân, c. II, s. 82; el-Emîn, A ‘yânü’ş-Şì‘a, c. V, s. 7.

${ }^{18}$ Ali en-Necdî Nâsıf, Târîhu'n-Naḥv, Dâru'l-Ma ârif, Kahire tsz., s. 40.

19 Dayf, el-Medârisü'n-nahviyye, s. 255; Mahmûd Huseynî Mahmûd, el-Medresetü'lBagdâdiyye, s. 261.

${ }^{20}$ Mahmûd Hüseyin Mahmûd, el-Medresetü'l-Bagdâdiyye, s. 261; Ferrûh, Târîhu'l-edebi'l'Arabî, c. II, s. 537.

${ }^{21}$ Brockelmann, Târîhu'l-edebi'l-'Arabî, c. II, s. 190.

22 Süyûtî, Buġyetü'l-vu 'ât, c. I, s. 496; Dayf, el-Medârisü'n-nahviyye, s. 256.

23 Yâkūt el-Hamevî, Mu'cemü'l-üdebâ', c. II, s. 811; Mahmûd Huseynî Mahmûd, elMedresetü'l Bag்dâdiyye, s. 261.

Turkish Academic Research Review - Türk Akademik Araştırmalar Dergisi https://dergipark.org.tr/tr/pub/tarr 
kardeşi Hüsrev'in çocuklarını eğitmesi için onu sarayına davet etmiştir. ${ }^{24}$ Şevki Dayf, müellifin Asker-i Mükrim ve Musul'un bazı şehirlerinde de ders verdiğini ve imlâ yoluyla ders okuttuğunu da zikreder. ${ }^{25}$ Adududdevle'nin Bağdat'ı almasıyla elFârisî’ tekrardan Bağdat'a dönmüş ve vefat edinceye kadar burada kalmıştır. ${ }^{26}$

\subsection{Eğitimi}

el-Fârisî ilim tahsiline doğduğu şehirde yani Fese'de başlamış ancak buradaki ilim halkaları, ondaki ilim iştiyakını karşılamamış olacak ki H. 307 yıllarında Bağdat'a ilim yolculuğuna çıkmıştır. ${ }^{27}$

Bağdat'ta bir süre kalan müellif burada döneminin önde gelen nahiv âlimlerinin ilim halkalarına katılacaktır. ${ }^{28}$ Onun yaşadığı dönemde, farklı gramer ekolleri (Basra Ekolü, Kûfe Ekolü gibi) mevcuttur. Ancak el-Fârisî ilim alırken en iyisine ulaşabilmek için ekoller arasında ayrım yapmamıştır. Örneğin Ebû İshak ezZeccâc (ö. 311/923), Ebû Bekir İbnü's-Serrâc (ö. 316/928), İbn Düreyd (ö. 321/933), Ebû Bekir Muhammed b. Ali el-Mebremân (ö. 345/956) el-Ahfeş es-Sağîr el-Bağdâdî (ö. 315/927) gibi Basra ekolüne mensup âlimlerin ilim halkalarında bulunmuştur. Diğer yandan da ilk Bağdat ekolünün temsilcilerinden özellikle de Ebû Bekir b. Hayyât'tan (ö. 320/932) dersler almış ${ }^{29}$, diğer taraftan da Sa'leb'in (ö. 291/ 904) öğrencisi, dönemindeki kurrâların şeyhi olan İbn Mücahid'den (ö. 320/932) kıraat eğitimi görmüştür. ${ }^{30}$ Bunların yanı sıra el-Fârisî, sadece dönemindeki âlimlerin bilgileriyle yetinmeyecek, Sîbeveyhi (ö. 180/796) ve diğerleri gibi önceki dönemin âlimlerinin kitaplarını da mütalaa edecektir. ${ }^{31}$ Hayatını ilme adayan elFârisî, vefat ederken de ilim erbabını düşünmüş ve malının üçte birini Bağdat'ta ki nahiv âlimleri için vasiyet etmiştir. ${ }^{32}$

\section{4. Hocaları}

el-Fârisî’nin hocalarından bazıları şunlardır:

1. ez-Zeccâc, Ebû İshâk İbrâhîm b. es-Serî b. Sehl (ö. 311/923).

\footnotetext{
${ }^{24}$ Ferrûh, Târîhu'l-edebi'l-'Arabî, c. II, s. 537.

25 Dayf, el-Medârisü'n-nahviyye, s. 256.

26 Dayf, el-Medârisü'n-nahviyye, s. 256.

27 Yâkūt el-Hamevî, Mu 'cemü'l-üdebâ', c. II, s. 812; Dayf, el-Medârisü'n-nahviyye, 255.

28 Yâkūt el-Hamevî, Mu 'cemü'l-üdebâ', c. II, s. 811.

29 Dayf, el-Medârisü'n-nahviyye, s. 256.

${ }^{30}$ Dayf, el-Medârisü'n-nahviyye, s. 256.

${ }^{31}$ Dayf, el-Medârisü'n-nahviyye, s. 256.

32 İbnü'l-Cezerî, Ġāyetü'n-Nihâye, c. I, s. 189.
} 
2. İbnü’s-Serrâc, Ebû Bekr Muhammed b. es-Serî b. Sehl el-Bağdâdî (ö. 316/929).

3. İbn Hayyât, Muhammed b. Ahmed b. Mansûr Ebû Bekr b. el-Hayyât, (ö. 320/932).

4. İbn Düreyd, Ebû Bekr Muhammed b. el-Hasen b. Dürey el-Ezdîel-Basrî (ö. 321/933).

5. Niftâveyh, Ebû Abdilleh Muhammmed b. Arafe b. Süleyman el-Atekî elEzdî el-Vasitî (ö. 323/935).

6. Ebû Bekir b. Mücahid, Ebû Bekr Ahmed b. Mûsâ b. el-Abbas b. Mücahid et-Temîmî (ö. 324/936).

\section{5. Öğrencileri}

el-Fârisî’nin öğrencilerinden bazıları şunlardır:

1. el-Ezherî, Ebû Mansûr Muhammed b. Ahmed (ö. 370/980).

2. Cessas, Ebû Bekr Ahmed b. Alî er-Râzî (370/981).

3. Adududdevle (ö. 372/983).

4. İbn Cinnî, Ebû'l-Feth Osman b. Cinnî (ö. 392/1002).

5. Cevherî, Ebû'n-Nasr İsmail b. Hammad el-Cevherî (ö. 400/1009).

6. Abdî, Ebû Talib Ahmed b. Bekr el-Abdî (ö. 406).

7. er-Rabeî, Ali b. İsa b. el-Ferec b. Salih Ebû'l-Hasen er-Rabeî (ö. 420/1029).

10. Ebû'l-Huseyn Muhammed b. Huseyn b. Muhammed b. Abdilvâris (ö. 467/1074).

\section{6. Eserleri}

1. el-Hücce li'l-kurrâ'i’s-seb 'a,

2. el-îzâh fi'n-nahv,

3. et-Tekmile,

4. Şerhu'l-ebyâti'l-müşkileti'l-i 'râb fi'ş-şi 'r,

5. el-Egfâl fìmâ agfelehü'z-Zeccâc mine'l-me 'ânî,

6. Mes 'eletü aksâmi'l-haber,

7. el-Mesâ'ilü'l-müşkiletü'l-ma 'rûfetü bi'l-Bagdâdiyyâ,

8. el-Mesẩilü'ş-Şî́râziyyât,

9. el-Mesâilü'l-Mensûra,

10. el-Mesâ'ilü'l-Bașriyyât,

11. el-Mesâ'ilü'l- 'Askeriyyât.

Turkish Academic Research Review - Türk Akademik Araştırmalar Dergisi 
Burada adı geçen eserler el-Fârisî’nin günümüze ulaşan eserlerinden bir kısmıdır. Kaynakların ifade ettiğine göre bunların dışında günümüze ulaşmayan eserleri de vardır.

\section{2. el-Fârisî’nin et-Tekmile Adlı Eseri}

el-Fârisî’ et-Tekmile isimli eserini, daha önce yazdığı el-1̂zâh isimli eserinde bulunmayan konuları tamamlayıcı mahiyette kaleme aldığını ifade etmiş̧ir. Zira Müellif et-Tekmile'nin girişinde 'I'râb ile alakalı konuları' biz kitabımızın birinci bölümü olan el-Îzâh isimli eserde zikrettik." şeklinde ifadelere yer vermektedir. ${ }^{33}$ Nitekim tabakât yazarları müellifin et-Tekmile'yi kaleme alma gerekçesini şu şekilde açıklamaktadırlar: "el-Fârisi el-Îzâh'ı yazıp Büveyhî Emîri Adududdevle'ye sunar. İbnü'l-Enbârî’nin naklettiğine göre, Adududdevle de müellife "Senin yazmış olduğun bu kitap, çocuklara uygundur." der. ${ }^{34}$ el-Fârisî de bu olayın üzerinden belli bir zaman geçtikten sonra et-Tekmile'yi yazıp kendisine takdim edince, Adududdevle, "Şeyh klzdl, kendisinin de bizim de anlayamayacağımız bir eser getirdi." der." ${ }^{35}$

el-Fârisî el-Îzâh ve et-Tekmile'de, kendisinden önceki dönemlerde yazılan Sîbeveyhi'nin (ö. 180/796) el-Kitâb isimli eserinde karışık halde bulunan sarf ve nahiv konularını birbirinden ayırıp düzenli bir şekilde tertip etmiş ve özetlemiş, Müberred'in (ö. 286/900) eseri el-Muktedab'ta karışık olarak kaleme alınan sarf ve nahiv meselelerini tertip edip tekrar eden aynı konuları çıkarmış yine Zeccâcî’nin (ö. 337/949) eseri el-Cümel'de yer alan sarf nahiv dışı tarih, ses bilim ve zarûrât-1 şi'riyye gibi konuları eserine almamıştır. ${ }^{36}$ Böylece el-Fârisî et-Tekmile'de sarf'ın en önemli konularını yüz yirmi iki bâbta toplamıştır. ${ }^{37}$

\section{1. et-Tekmile Üzerine Yazılan Șerhler}

Kâtip Çelebi (ö. 1067/1657), Abdülkâhir el-Cürcânî’nin et-Tekmile'ye otuz ciltlik el-Muğnî isimli basit bir şerh yazdığını, sonra bunu el-Mukteșid isimli bir eserde ihtisâr ettiğini, yine aynı müellife ait $\hat{I} c a ̂ z$ isimli yalnız el-Îİâh' 1 ihtisâr eden

\footnotetext{
${ }^{33}$ Fârisî, et-Tekmile, s. 182.

34 İbnü'l-Enbârî, Nüzhetü'l-elibbâ, s. 233.

35 Yâkut el-Hamevî, Mu'cemu'l-üdebâ, c. II, s. 813; Süyûtî, Buğyetu'l-Vuât, s. 496.

36 Yahya Mîr Âlem, "Kitâbu'l-Îżâh mekânetühû ve hașâișuhû”, Mecelletü Mecmei 'l-Lugati'lArabiyye bi Dımaşk,1993, sayı: 68, s. 305.

${ }^{37}$ Mîr Alem, "Kitâbu'l-Îżâh Mekânetühû ve Hูașâișuhû”, 305.
} 
bir şerhinin bulunduğunu bildirmiştir. ${ }^{38}$ Abdulkâhir el-Cürcânî et-Tekmile üzerine yazılan tek şerh olan el-Mukteșid'in zeylinde adı geçen eserin şiirlerinin şerh edildiği Kazım Bahr el-Murcan tarafından tespit edilmiştir. Yazar bu eserin İstanbul Ragıp Paşa Kütüphanesinde olduğunu ifade etmiştir. ${ }^{39}$

\section{2. el-Fârisî'nin et-Tekmile'de Takip Ettiği Metot}

el-Fârisî et-Tekmile isimli eserine Adududdevle'ye dua ifadeleri ile başlar. Müellif eserinde bölümlendirmelere, tanımlara, sembollere, ortaya koyduğu kuralları semâ, kıyâs gibi farklı yöntemlerle temellendirmelere yer verir. Bunların yanı sıra bazı kuralların anlatımında farklı dil ekollerinden ve bu ekollere mensup dilcilerden yararlanır.

Müellif ilk olarak eserinin başında nahiv ilmini tanımlayıp bölümlere ayırır. Bu konuda nahvin iki kısım olduğunu, birinci kısma el-f̂zâh isimli eserinde yer verdiğini ikinci kısmın ise bu eserde yer alacağını belirtir. ${ }^{40}$ Esere genel olarak bakıldığında baş tarafında yer alan bölümlendirmelerin neredeyse eserin tamamına egemen olduğu görülmektedir.

Bölümlendirmelerine örnekler:

1. İki sâkinin iltikâ-ı babında: "İki sâkin ya bir kelimede veya iki kelimede ictimâ eder. Ĕger bir kelimede ictimâ etti ise ya aynı cinstendir veya farklı cinstendir." ${ }^{41}$

2. Tesniye ve cemi bâbında: "Tesniye bir isim ya sahîhtir veya mu'tel'dir. Mu 'tel: Sonu elif veya mâ kabli meksûr yê veya hemze olandır. Eğer sonu elif ise bu iki kısımdır: 1. Üç harflidir, 2. Üç harften fazladır."

3. Müennes alâmeti bitişen isimler bâbında: "İsme bitişsen müfred elifi, ya müennese mahsûs bir yapıda veya müzekker ile müennes için ortak kullanılan bir yapıdadır. Müennese mahsûs olan kalıplardan bazılarl: 1. فُ Kalibinda olanlardır.

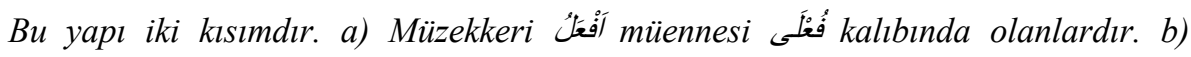

\footnotetext{
${ }^{38}$ Kâtib Çelebi, Keşfü'z-ẓunûn, nşr: Mehmet Şerafeddin Yaltkaya, Dâru İhyâi Türâsi'l- 'Arabî, Beyrut tsz, c. I, s. 212.

39 Kâzım Bahr el-Mürcân, "Mukaddime", et-Tekmile, Ebû Alî el-Fârisî, Âlemü’l-Kütüb, Beyrut 1431/2010, s. 66.

${ }^{40}$ Fârisî, et-Tekmile, s. 180.

${ }^{41}$ Fârisî, et-Tekmile, s. 185.

${ }^{42}$ Fârisî, et-Tekmile, s. 238.
}

Turkish Academic Research Review - Türk Akademik Araştırmalar Dergisi https://dergipark.org.tr/tr/pub/tarr 


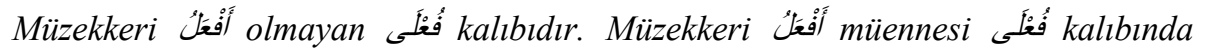
olanlar iki farkll şekilde kullanılır..."43

Müellifin yaptığı bu işlemin, meselelerin anlaşılması noktasında büyük yararı vardır. Zira bu şekilde konular daha kolay takip edilebilmektedir.

el-Fârisî'nin et-Tekmile'de tanımlara da yer vermektedir. Eserde yer alan tanımlardan bazıları şunlardır:

İlm-i nahiv: Arap Dilinde istikrâ (tüme varım) yöntemiyle elde edilen kuralları bilmektir. ${ }^{44}$

İşmâm: Harfi sâkin olarak okuduktan sonra dudakları yummak ve lafzı sessiz bir şekilde raf veya damme ile okumaya hazır hale getirmektir. ${ }^{45}$

Revm: Ağzı doldurmaksızın sesi hafif bir şekilde çıkarmaktır. ${ }^{46}$

Birinci kısım muzâfün ileyh: Kasd edilen isme muzâf olup, ona muzâf olmakla marife olandır.

İkinci kısım muzaâfün ileyh: Kasd edilen bir isme muzâf olmayıp, birincisinin kendisi ile hususileşmediği isme muzâf olmaktır. ${ }^{47}$

Maksûr: Sonuna müenneslik veya ilhâk için elif ziyade olan veya vâv ve yâ'dan çevrilmiş elif bulunandır. ${ }^{48}$

Hakîkî müennes: Karşısında erkeği olandır.

Gayrı hakîkî müennes: Müenneslik yalnız lafızla alakalı olup, tahtında başka bir anlamı olmayandır. ${ }^{49}$

İdğâm: Sâkin bir harfi, aralarına hareke veya vakıf girmeksizin misline bitiştirmek ve bundan dolayı dili bir defa yukarı kaldırmaktır..$^{50}$

Müellif bu tanımlamaların bazısında betimleyici ifadeler kullanmıştır. Örneğin işmâmın tanımında sükûndan sonra dudakları yummak şeklinde sözlerle işmâmda dudak hareketlerinin nasıl olacağını veya idğâmın tanımında dili kaldırmaktır şeklinde ifadelerle idgâm yaparken dilin hareketinin nasıl olacağını betimleyerek anlatır. Bunların yanında bazı terimlerden bahsederken de farklı ifadeler kullanır. Örneğin izâfet yerine

\footnotetext{
${ }^{43}$ Fârisî, et-Tekmile, s. 317.

${ }^{44}$ Fârisî, et-Tekmile, s. 180.

${ }^{45}$ Fârisî, et-Tekmile, s. 205.

${ }^{46}$ Fârisî, et-Tekmile, s. 205.

${ }^{47}$ Fârisî, et-Tekmile, s. 268.

${ }^{48}$ Fârisî, et-Tekmile, s. 285.

${ }^{49}$ Fârisî, et-Tekmile, s. 307

${ }^{50}$ Fârisî, et-Tekmile, s. 614.
} 
bütünden ayrlmaz, ifadesi bunlardan biridir. $^{51}$ Bazı durumlarda hükümleri bildirirken önce genel kurallar şeklinde verip sonra detaylı anlatıma geçer. Örneğin “ilk harfi meftûh olan صَحْرَاء gibi kelimeler sadece gayri munsarif olur." müellif' in zikrettiği genel kurala örnek verilebilir.

el-Fârisî eserinde Arap yazı hattında bulunan ve kendisine anlam yüklenen bazı sembollerden bahseder. Örneğin harf üzerindeki $خ$ harfinin sükûnu, ش harfinin taz'îfi sembolize ettiğini bildirir. ${ }^{53}$

el-Fârisî eserinde yer verdiği görüşlerin bir kısmını kendi hocalarından

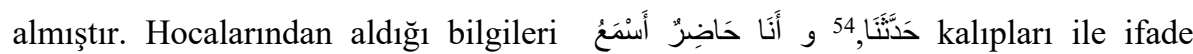
ederken ${ }^{55}$ sözlük yazarlarından Ehlü'l-luga ${ }^{56}$ ifadesi ile bahsetmektedir.

el-Fârisî eserinde ortaya koyduğu kuralları semâ, kıyâs, ta‘'îl, lafız ve mana üzerine hamlederek temellendirir.

el-Fârisî’nin semâ ile istişhâda verdiği önemi öğrencisi İbn Cinnî şu sözlerle ifade eder “ Bir şey hakkinda semâ vârid olduğunda başka bir matlûb kalmaz ve kiyâsdan semâa dönülür." ${ }^{57}$ Dolayısıyla müellife göre semâ’1n olduğu yerde kıyâsa yer yoktur. el-Fârisî semâ konusunda selef âlimleri gibi Kur'ân ayetlerini temel kabul eder. Kur'ân ile istişhâd ederken bazı yerlerde sadece bir ayete, bazı yerlerde birden fazla ayete ${ }^{58}$ yer verirken farklı kırâatlerden de istifâde eder. Örneğin لَكَنَ üzerine vakıf konusunda iki kraatten daha güzeli ifadesinde bulunur. ${ }^{59}$ Ayrıca günümüze ulaşan ve şu anda tüm çevrelerce makbul görülen Osman (r.a.) mushafının yanı sıra Abdullah b. Mesûd'un (r.a.) kaleme aldığı mushaf ile de istişhâdda bulunarak ondan Abdullah'ın harfinde olduğunu iddia ettiler şeklinde bahseder. ${ }^{60}$ Müellifin bu şekilde istişhâdda bulunduğu toplam 188 ayet vardır. Eserde bu kadar ayetle istişhâdda bulunulması İbn Mücâhid'den kırâat eğitimi alan müellifin Kur'ân ayetlerine ne kadar önem verdiğini ve ayetlere ne

\footnotetext{
${ }^{51}$ Fârisî, et-Tekmile, s. 463.

52 Fârisî, et-Tekmile, s. 351.

53 Fârisî, et-Tekmile, s. 205.

${ }^{54}$ Fârisî, et-Tekmile, s. 296.

${ }^{55}$ Fârisî, et-Tekmile, s. 246.

56 Fârisî, et-Tekmile, s. 526.

57 İbn Cinnî, Ebü’l-Feth Osmân b. Cinî el-Mevsılî el-Bağdâdî, el-Münșıf, thk. İbrahim Mustafa, Abdullah Emin, İdâretü'l-İhyâî Türâsi'l-Kadîm, Mısır 1373/1954, s. 278-279.

${ }^{58}$ Fârisî, et-Tekmile, s. 356.

${ }^{59}$ Fârisî, et-Tekmile, s. 218.

${ }^{60}$ Fârisî, et-Tekmile, s. 463.
}

Turkish Academic Research Review - Türk Akademik Araştırmalar Dergisi https://dergipark.org.tr/tr/pub/tarr 
kadar hâkim olduğunu gösterir. Ayrıca bu durum kırâati seb'anın kaynakları üzerine yazdığı el-Hücce li'l-kurrâ'i's-seb 'a (el-Hücce fi 'ileli'l-kırấati's-seb ')eserinden de anlaşılmaktadır. Hadislerle istişhâd, müellifin yaşadığı dönemde yeni başlamıştır. Bazı eserlerinde hadislerle istişhâda yer veren el-Fârisi et-Tekmile'de hadislerle istişhâdda bulunmamıştır.

Kaynaklar el-Fârisî’nin hayatında yaşlılıkla alakalı yazdığı üç beytin dışında şiir yazmadığııı ifade eder. Bununla beraber müellif et-Tekmile'de 284 şiirle istişhâdda bulunmuştur. Eser üzerine tahkik yapan Kâzım Bahr el-Mürcân 55 şiirin yazarının et-Tekmile'de geçtiğini, 160 şiirin şairlerini ise kendi gayretleri ile farklı eserlerde tespit ettiğini ancak 33 şiirin şairinin isimlerini bulamadığını ifade etmektedir. el-Mürcân'ın ifadesine göre eserde yer alan şiirlerden 20'si Zu'rrumme'ye (117/735), 14'ü Hüzeyl kabilesine, 12'si A ‘şâ’ya (ö. 7/629), 11'i Cerîr'e (ö. 110/728), 8'i Ebü'ş-Şa'sâ' Abdullâh b. Rü’be b. Accâc'a (ö. 97/715), 7'si Ferazdak'a (114/732), 6’s1 Ru‘be (ö. 145/762), Temîm b. Ebî İbn Mukbil (ö. 70/689) ve el-Kümeyt'e (ö. 126/744), 5'i Evs'e (ö. 620 [?]), 3'ü İmruülkays'a (ö. 25/645), Tarafe b. el-Abd'e (ö. 564), Hassân b. Sâbit'e (ö. 60/680), Züheyr'e (ö. 609[?]), A'şâ Benî Nehşel Esved b. Ya'fur’a (hicretten 22 yıl kadar önce vefat etmiştir), Humeyd'e (ö. 70/689), Lebîd b. Rebîa'ya (ö. 40/660), Abîd b. Ebras’a (ö. 555 [?]), 2'si Ömer b. Ebî Rebîa (93/711), Ebu'n-Necm el-Iclî (ö 125/743), Teebbeta Şerran (ö. 540[?]), Ümeyye b. Salt (8/630), Bişr b. Ebû Hâzım (ö. 22/597), Nâbiga el-Ca‘dî (ö. 65/685), Antere (ö. 614 m. [?]), Ebû Nahîle es-Sa‘dî’ye (ö. 145/762) aittir. ${ }^{61}$ Zikri geçen şairlerin haricinde sadece bir şiiri ile istişhâdda bulunduğu ancak ismini burada zikretmediğimiz şairler de vardır. Ayrıca recez şairlerinin şiirlerine de eserinde yer vermiştir.

Semâ konusunda sözlerine başvurulan Arap kabilelerinin başında Ehl-i Hicâz ${ }^{62}$ ve Benî Temîm ${ }^{63}$ gelmektedir. Hatta eserde bu iki kabilenin ismi neredeyse sürekli olarak beraber yer almaktadır. Bu da el-Fârisî’nin sözü geçen iki kabilenin fesahatlarına güvendiğini gösterir.

el-Fârisî'nin kuralları kıyâs ile temellendirmesine gelince, bu konu ismiyle özdeşleştiği bir konudur. et-Tekmile incelendiğinde kuralların temellendirilmesinde aklî deliller daha fazla olduğu görülecektir. Müellif eserinde kullandığı kıyâsı; üzerine kıyâs edilebilir veya üzerine kıyâs edilemez şeklinde ayırır. Örneğin ismi mensûbu anlatırken "İsmi mensûba etki eden değişim iki klsımdır: birincisi teorilerle

\footnotetext{
${ }^{61}$ Mürcân, "Mukaddime”, s. 112-113.

${ }^{62}$ Fârisî, et-Tekmile, s. 185-226-227.

${ }^{63}$ Fârisî, et-Tekmile, s. 185-226-227.
} 
uyumlu olmayan ve sürekli olmayandır, ikincisi uyumlu ve sürekli olandır. Uyumlu ve sürekli olmayanin hükmü; olduğu şekilde muhafaza edilip üzerine kyyâs edilmemesidir. Uyumlu ve sürekli olanın hükmü kendileri üzerine kiyâs edilmektir." ${ }^{64}$ şeklinde konuya açıklık getirmektedir.

Yine ismi maksûr konusunda "Bir kısmı kıyâsidir, diğer bir kısmı kıyâsi olmayıp semâ" ile bilinir demektedir. Müellifin kıyâsa ilişkin et-Tekmile'de kullandığı ifadelerden bazıları şunlardır:

\begin{tabular}{|c|c|}
\hline Üzerine kıyâs edilir. & قِيِسَ عَلْيه \\
\hline Kıyâsa en uygun olandır. & 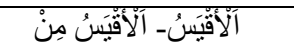 \\
\hline Ashâbımızın kıyâsına göre. & عَلَي قِيَّاسِ أصنْحَابِنَا \\
\hline Kıyâs yönünden. & مِنْ جِهَهة ألِْيَاسِِ \\
\hline Üzerine kıyâs edilmez. & وَلا يُقَاسُ عَلَيه \\
\hline Kıyâsa yol yoktur. & 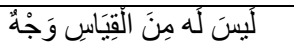 \\
\hline $\begin{array}{l}\text { Kıyâsa uygundur, fakat Araplar kıyâstan } \\
\text { döndüler. }\end{array}$ & ذَالِلكَ \\
\hline Kıyâs dışıdır/Kıyyâsa aykırı olarak. & عَلَّي غَيْرِ الِْقِيَاسِ \\
\hline Kıyâstan çıkmaktır. & آلَخُرُوجُج عَنْ الَفِِيَاسِ \\
\hline Kıyâs devam etmeyenlerdendir. & 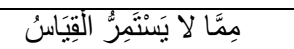 \\
\hline
\end{tabular}

Müellif kıyâs ile temellendirdiği hükümleri geçerlilik açısından da değerlendirmelere tabi tutar. Bu konuda hiyerarşik olarak şu sıralamanın yapıldığı söylenebilir:

\begin{tabular}{|c|c|}
\hline Üzerine ittifak edilmiştir. & 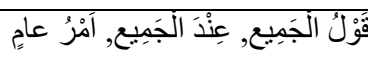 \\
\hline Kullanımda daha çok-en çok. & 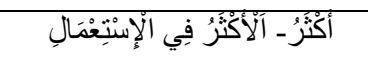 \\
\hline Azdır üzerine kıyâs edilemez. & 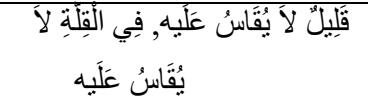 \\
\hline $\begin{array}{l}\text { Az kullanıldığ } 1 \text { için buna itibar } \\
\text { edilmez. }\end{array}$ & 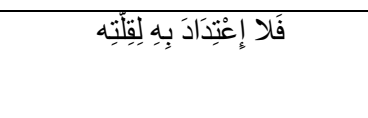 \\
\hline Azdır, benzeri yoktur. & 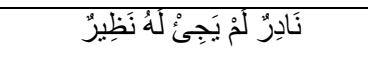 \\
\hline Daha fazlasına geçmediler. & لَمْ يُجَاوِزو \\
\hline Şazdır. & شَاذَّ, و قَدْ شُنْ \\
\hline Kıyâs ve istimâl yönünden şazdır. & 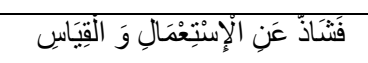 \\
\hline Kerihtir, Araplar kerih buldular. & 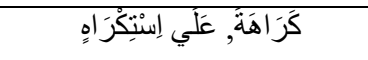 \\
\hline
\end{tabular}

${ }^{64}$ Fârisî, et-Tekmile, s. 255.

Turkish Academic Research Review - Türk Akademik Araştırmalar Dergisi https://dergipark.org.tr/tr/pub/tarr 


\begin{tabular}{|c|c|}
\hline Kabîh olarak. & قََبِيحاً \\
\hline $\begin{array}{l}\text { Caiz değildir, kabul etmediler, } \\
\text { kullanılmadı. }\end{array}$ & 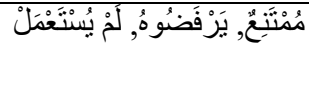 \\
\hline
\end{tabular}

el-Fârisî hükümleri temellendirirken semâ veya kıyâs türünden bir şey bulunmadığında kendi çıkarımlarıyla ta'lîl (gerekçelendirme) yapar. Gerekçelendirmeler yaparken kullandığı sözlerden bir kısmı şunlardır: آَالَتَرَى, لِالَنَ, يَدُْ عَلَي ذَّلِكَ (görmüyor musun, çünkü, buna delildir.)

el-Fârisî hükümleri temellendirirken kimi zaman lafız kimi zaman mana üzerine hamlederek hüküm ortaya koyar.

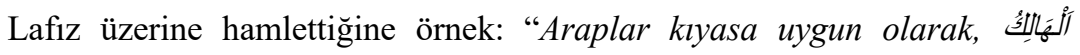
kelimesinin cemisinde mana üzerine hamletmekten daha çoktur. Zira Arap dilinde دَامِرّددَامِرُونَ derler fakat

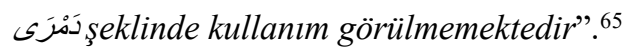

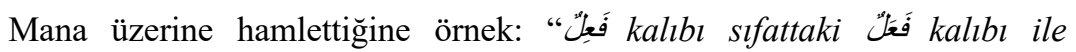

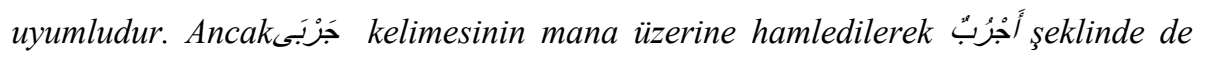
cemilenmesi caizdir". ${ }^{66}$

Müellif bunların yanı sıra anlatımda diyalektik yöntemini de kullanır. Örneğin "Sen Arapların semâyl أْلَجْبَاءُ diye niçin isimlendirdiler dersen"67 şeklinde önce soruyu sorar. Sonra arkasından "Şu şekilde söylenir" diye cevap verir.

Müellif eserini oluştururken belli bir gruba mensup dilcinin görüşlerini körü körüne benimsemeyip, Basralıların ve Kûfelilerin görüşlerine yer vermiştir. $\mathrm{Bu}$ nedenle et-Tekmile'de Basralılardan Halîl b. Ahmed, Sîbeveyhi, Asmaî, Ebû Zeyd, Müberred ve benzeri âlimlerin görüşlerinden bahsetmektedir. Ancak bunların içerisinden Sîbeveyhi ve Ebû Zeyd'in ismi ön plandadır.

Örneğin Sîbeveyhi'nin ismi eserde otuzdan fazla yerde geçmektedir. Müellif bir çok konuda Sîbeveyhi ile aynı görüşü paylaşırken birkaç konuda ona muhalefet etmektedir. Görüşüne katıldığı yerlerden bazıları:

1. “" Naṣb halinde ise kâffetha hareke almaz. Sîbeveyhi'nin görüşünde böyledir." el-Fârisî, Sîbeveyhi’nin bu görüşünü şu şekilde temellendirir: "Râ harfinin sâkin olması gerekli değildir. Bunun nedeni kelimeye elif lâm dâhil olmazdan önce vakuf durumunda tenvîn yerine (صَادَفْتُ نَقْرَ) de olduğu gibi başına elif lâm yerine sonuna elif getirilmiştir". ${ }^{6}$

\footnotetext{
${ }^{65}$ Fârisî, et-Tekmile, s. 484.

${ }^{66}$ Fârisî, et-Tekmile, s. 484.

${ }^{67}$ Fârisî, et-Tekmile, s. 338.

${ }^{68}$ Fârisî, et-Tekmile, s. 193.
} 


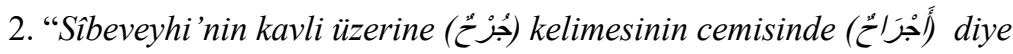
şiir zaruretinden dolayı gelmesi cazidir". ${ }^{69}$

3. Sîbeveyhi bazı Araplar'ın (آلْعَلَْي) kelimesini müennes getirdiklerini iddia etti. $^{70}$

Müellif, burada zikrettiğimiz konuların dışında daha bir çok meselede Sîbeveyhi ile aynı görüştedir.

el-Fârisî'nin Sîbeveyhi'nin görüşüne katılmadığg yerler çok azdır.

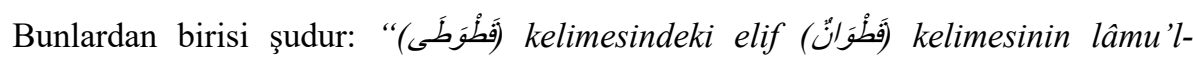

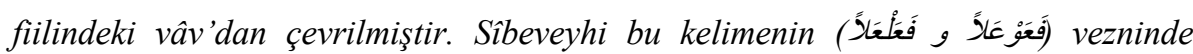
olmasına cevaz verdi. Ancak ikincisi daha uygundur". ${ }^{71}$ Burada Sîbeveyhi her iki seçeneğe eşit olarak cevaz verirken el-Fârisî ikincisinin daha uygun olduğu görüşünü savunarak ona muhalefet etmektedir.

el-Fârisî et-Tekmile'de Kûfelilerden Kisâî, Ferrâ, Sa'leb gibi âlimlerin görüşlerini zikretmiştir. $\mathrm{Bu}$ alimlerin içinden Sa'leb'in sarf ve lugat ile ilgili görüşlerine yer verip ona karşı çıkmazken, bir çok şiiri ile de istişhâdda

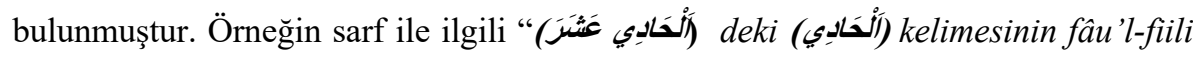

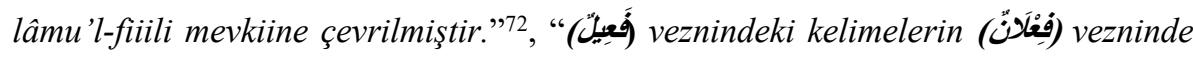
cemi mükesser gelmesi azdır."73 görüşleri bunlardandır.

Yine el-Fârisî eserinde Kûfelilerden Kisâî'nin (ö. 189/805) görüşlerine yer vermekle beraber ona muhalefet etmiştir. Örneğin (آَلْحَمْنَةُ الَْأَنَوَابِ) şeklinde muzâf ve muzâfun ileyhin elif-lâm'lı gelmesi konusunda Kisâî’nin cevâz verdiği görüşünü zikrettikten sonra Ebû Ömer'in “Bu şekilde Fașîh olmayan Araplar kullanmaktadır.” sözlerini nakleder. Daha sonra müellif, Kisâî’nin görüşüne “Bunun sürekli olmaması zayıf olduğunu gösterir, Zurrimme'nin beytide Kisâî’nin rivayetine muhaliftir" sözleri ile karşı çıkar. ${ }^{74}$

Ayrıca eserde az da olsa Bağgâdiyyûn ve ba 'zu'l-Băgdâdiyyûn şeklinde Bağdatlılardan da bahsedilmektedir. Ancak müellif birkaç yerde zikrettiği

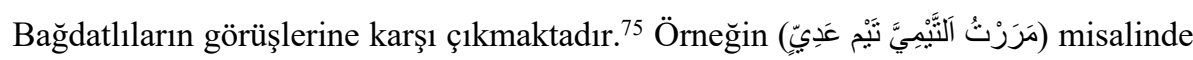
mecrûr (تَّْن kelimesini, Bağdatlilar neseb yâ'sından bedel olarak tevil ederler. Ancak

\footnotetext{
${ }^{69}$ Fârisî, et-Tekmile, s. 420-421.

${ }^{70}$ Fârisî, et-Tekmile, s. 324.

${ }^{71}$ Fârisî, et-Tekmile, s. 557.

72 Fārisī, et-Tekmile, thk. Kāẓım Baḥr el-Murcān, 273.

73 Fārisī, et-Tekmile, thk. Kāẓım Baḥr el-Murcān, 447.

${ }^{74}$ Fârisî, et-Tekmile, s. 276-277.

75 bkz. Fârisî, et-Tekmile, s. 253-396-397-581.
}

Turkish Academic Research Review - Türk Akademik Araştırmalar Dergisi 
el-Fârisî onlara muhalefet ederek şöyle söyler "Bize göre bu sahih değildir. Zira bu kelime (صَاحِبَ تَتْيَ عَدِيّ) takdirinde olup gizli muzâfin, muzafi ileyhi durumundadır" ${ }^{76}$

\section{Sonuç}

el-Fârisî nahiv, sarf, kırâat ve lugata dair günümüze ulaşan ve ulaşmayan otuzdan fazla eser bırakmıştır. Eserlerinden bir kısmını Hamdânilerin emiri Seyfüddevle ve Büveyhîlerin emiri Adududdevle gibi devlet adamlarına ithâf etmiş̧ir. Ayrıca kaleme aldığı eserlerinin bir kısmı tahkik edilmiş diğer bir kısmı ise tahkik edilmeyi beklemektedir. Müellif içerisinde bulunduğu dönemin önde gelen âlimlerinden ders almakla beraber kendisinden önceki dönemde kaleme alınan sarf ve nahiv eserlerini de okumuştur.

el-Fârisî’nin yaşadığı dönemde İslâm şehirleri ilim ve medeniyet merkezidir. Bu nedenle o çağdaşı birçok âlim gibi farklı İslâm şehirlerine seyahatler gerçekleştirmiş, her birinde ilim tahsil etmiş ve dersler vermiştir. Müellifin yaşadığ döneme kadar telif edilen çoğu eserde sarf ve nahiv kuralları iç içe iken o, nahve dair kuralları el-Îzâh ve çoğu sarfa dair kuralları et-Tekmile'de bir araya getirmiştir. el-Fârisî et-Tekmile'yi başından sonuna kadar kelimedeki değişimi baz alarak hazırlamıştır. Müellifin yazdığı el-f̂zâh isimli eseri medreselerde üç yüz yıla yakın bir süre temel nahiv eseri olarak okutulmuş ve farklı İslâm beldelerinde üzerine birçok şerhler yazılmıştır. Ayrıca el-Fârisî gelecek dönemler için dil alanında yenilikler getirecek İbn Cinnî, lügat alanında etkili olacak Cevherî gibi öğrenciler yetiştirmiştir.

Müellif eserini oluştururken kendinden önceki dilcilerden yararlanmıştır. Bu alanda et-Tekmile'de Basralılardan Halîl b. Ahmed, Sîbeveyhi, Asmâ̂, Ebû Zeyd, Müberred ve benzeri âlimlerin görüşlerine yer vermiştir. Ancak bunların içerisinden Sîbeveyhi ve Ebû Zeyd'in ismi daha çok geçmektedir. Yine Kûfelilerden Kisâi, Ferrâ, Sa'leb gibi âlimlerin görüşlerini zikretmiş, bunların içinden Sa'leb'in görüşlerine muhalefet etmemiştir. Dil ekolleri bazında düşünüldüğünde en çok Basralıların görüşleri dikkat çekmekle beraber yer yer Kûfelilerin görüşleri de görülmektedir. Bazı yerlerde de Bağdatlılardan da bahsedilse de müellif onlara muhalefet etmektedir.

el-Fârisî et-Tekmile'deki kuralları semâ, kıyâs, ta'lîl gibi yöntemlerle temellendirmiştir. Ancak bunların içerisinden semâ öncelikli kaynağı olmuştur.

el-Fârisî et-Tekmile'de semâ ile temellendirme yaparken önceliği Kur'ân ayetlerine vermiş akabinde Arap şiiri, Arap sözü ile istişhâda devam etmiş, ancak

\footnotetext{
${ }^{76}$ Fârisî, et-Tekmile, s. 253-254.
} 
hadislerle istişhâdda bulunmamıştır. Arap kabilelerinden Hicâzlılar ile Benî Temim'e ayrı önem vermiş onların lugatını temel kabul etmiştir.

Kıyâs ile temellendirme el-Fârisî’nin en maharetli olduğu konudur denilebilir.

et-Tekmile'de sarf ile ilgili konular anlatılırken bazen konu başlarında bazen de konu ortasında farklı bölümlendirmeler yapılmıştır. Bunların yanı sıra tanımlamalara da yer verilmiştir.

\section{Kaynakça}

Askalânî, Ebü'l-Fazl Şihâbüddîn Ahmed b. Alî b. Muhammed, Lisânü'l-mîzân, thk. Abdulfettah Ebû Gudde, Dâru'l-Beşâiri'l-İslâmiyye, Beyrut 1423/2002.

Brockelmann, Carl, Târîhu'l-edebi'l-'Arabî, trc. Abdülhalîm en-Neccâr, Dâru'lMeârif, Kahire tsz.

Cezerî, Ebü'l-Hayr Şemsüddin Muhammed b. Muhammed b. Muhammed b. Alî b. Yûsuf, Gâyetü'n-Nihâye fì tabakâti'l-kurrâ', thk. G. Bergstraesser, Dârü'lKütübi'l-İlmiyye, Beyrut 1971.

Dayf, Şevkî, el-Medârisü'n-nahviyye, Dâru'l-Ma'ârif, Kahire tsz.

Ebû Alî el-Fârisî, Hasen b. Ahmed b. Abdilgaffâr, et-Tekmile, thk. Kâzım Bahr elMürcân, Âlemü'l-Kütüb, Beyrut 1431/2010.

Ferrûh, Ömer, Târîhu 'l-edebi'l- 'Arabî el-A 'suru'l-Abbâsiyye, Dâru'l-İlm li'lMelâyîn, Beyrut 1401/1981.

Hatîb el-Bağdâdî, Ebû Bekr Ahmed b. Alî b. Sâbit, Târîhu Medîneti 's-selâm, thk. Beşşâr Avvâd Ma'rûf, Dâru'l-Garbi'l-İslâmî, Beyrut 1422/2001.

İbn Cinnî, Ebü'l-Feth Osmân b. Cinî el-Mevsılî el-Bağdâdî, el-Münșıf, thk. İbrahim Mustafa, Abdullah Emin, İdâretü'l-İhyâ̂i Türâsi'l-Kadîm, Misır 1373/1954.

İbn Hallikân, Ebü'l-Abbâs Şemsüddîn Ahmed b. Muhammed b. İbrâhîm b. Ebî Bekr b. el-Bermekî el-İrbilî, Vefeyâtü'l-a yân ve enbâ'ü ebnâ'i'z-zamân, thk. İhsan Abbas, Dâru Sâdır, Beyrut tsz.

İbnu'n-Nedîm, Ebü’l-Ferec Muhammed b. Ebî Ya 'kûb İshâk b. Muhammed b. İshâk en-Nedîm, el-Fifrist, Dâru'l-Ma'rife, Beyrut tsz.

İbnü'l-Enbârî, Ebü'l-Berekât Kemâlüddîn Abdurrahmân b. Muhammed b.

Ubeydillâh, Nüzhetü 'l-elibbâ' fi tabakâti' 'l-üdebâ', thk. İbrahim es-Sâmirâî, Mektebetü'l-Menâr, Ürdün 1405/1985.

İbnü'l-Kıftî, Ebü'l-Hasen Cemâlüddîn Alî b. Yûsuf b. İbrâhîm b. Abdilvâhid eşŞeybânî, İnbâhü'r-ruvât 'alâ enbâhi'n-nühât, thk. Muhammed Ebû'l-Fadl İbrahim, Dâru'l-Fikri'l-Arabî, Kahire, 1406/1986.

Mahmûd, Hüseyin Mahmûd, el-Medresetü 'l-Bagdâdiyye fí Târîhi'n-Nahvi'l-Arabî, 
Dâru Ammâr, Amman tsz.

Muhsin Emin, Ebû Muhammed el-Bâkır Muhsin b. Abdilkerîm b. Alî el-Hüseynî elÂmilî, A 'yânü'ş-Şî‘'a, thk. Hasan el-Emîn, Beyrut: Dâru’t-Teâruf li’lMatbûa‘, Beyrut 1304/1983.

Mürcân, Kâzım Bahr, "Mukaddime”, et-Tekmile. Ebû Alî el-Fârisî, Âlemü'l-Kütüb, Beyrut 1431/2010.

Nâsıf, Ali en-Necdî, Târîhu'n-Nahv, Dâru'l-Ma ârif, Kahire tsz.

Süyûtî, Ebü'l-Fazl Celâlüddîn Abdurrahmân b. Ebî Bekr b. Muhammed el-Hudayrî eş-Şâfi, Bugyetü'l-vu 'ât fí tabakâti'l-lugaviyyîn ve'n-nühât, thk. Muhammed Ebü'l-Fadl İbrâhim, Matbaatu İsâ el-Bâbî el-Halebî ve Şurekâuhû, by. 1384/1964.

Vâlid Ebbâh, Muhammed el-Muhtâr, Târîhu'n-nahvi'l-Arabîfi'l-Meşriḳ ve'lMegrib, Dârü'l-Kütübi'l-İlmiyye, Beyrut 1429/2008.

Yahya Mîr Âlem, “Kitâbu'l-Îzâh mekânetühû ve hașâișuhû”, Mecelletü Mecmeı'lLugati'l-Arabiyye bi Dımaşk 68 (1993).

Yâkût el-Hamevî, Ebû Abdillâh Şihâbüddîn Yâkût b. Abdillâh el-Hamevî elBağdâdî er-Rûmî, Mu 'cemü'l-üdebâ' (İşâdü'l-erîb ilâ ma 'rifeti'l-edîb). thk. İhsân Abbâs, Dâru'l-Garbi'l-İslâmî, Beyrut 1993.

Zübeydî, Ebû Bekr Muhammed b. el-Hasen el-Endülûsî, Tabakâtü'n-nahviyyîn ve’lLugaviyyîn, thk. Muhammed Ebû'l-Fadl İbrahim, Dâru'l-Ma'ârif, Kahire tsz. 